\title{
Investigating the Effect of Light Reaction Exercises on Agility-Quickness and Reaction Time of the U-20 Football Players
}

\author{
Mehmet Onur Vurmaz ${ }^{1}$, Bergun Meric Bingul ${ }^{2}$ \\ ${ }^{1}$ Master Stud., Kocaeli University, Faculty of Sport Science, Turkey \\ ${ }^{2}$ Assoc.Prof.Dr., Kocaeli University, Faculty of Sport Science, Turkey \\ Correspondence: Bergun Meric Bingul, Assoc.Prof.Dr., Kocaeli University, Faculty of Sport Science, Turkey.
}

Received: September 8, 2018

Accepted: October 27, $2018 \quad$ Online Published: November 29, 2018

doi:10.11114/jets.v6i11a.3808

URL: https://doi.org/10.11114/jets.v6i11a.3808

\begin{abstract}
The aim of this study is to investigate the effect of light reaction exercises on agility-quickness and reaction time of the U-20 Eootball Players. 20 male football players from the YeniMalatyaspor participated in this study voluntarily. T-test for agility-quickness, foot reaction test with Light-Trainer device for foot reaction speed were done before and after trainings. While the control group continued with the standard training, the exercise group performed the standard training exercises with Light-Trainer device for eight weeks. According to the results, the exercise group improved statistically $(p<0.05)$. It was observed that the exercises performed with Light-Trainer device had positive effects on agility-quickness and reaction speed over U-20 football players and improved their features. İt was thought that such education would be very useful in the cognitive training of young athletes.
\end{abstract}

Keywords: light-Trainer, agility-quickness, reaction

\section{Introduction}

Light Reaction Exercises play a very important role in the basic motoric properties in football as well as in its compound motoric properties. Because the motoric features in football are in constant contact with each other and complement each other (Koç and Aslan 2010).

According to Aydos and others (2009), physical structure affecting performance and success is just one of the factors. The physical structure required for sports is a branch of other performances such as strength, power, flexibility, speed, durability and quickness and when combined with their achievements, affects the success of the athlete positively.

Soccer continuity and durability are required by many aerobic and anaerobic capacities because it is a sports sport that is used extensively, the basic motor it is necessary to have continuity and resilience in its characteristics. It is important to provide coordination and flexibility during the continuity as well as to ensure continuity of strength, quickness and increase capacity. Although we do not directly coordinate and flexibilize into the compound motor properties, parameters such as consistency in speed, continuity of the glove and coordination and flexibility to use the force in the soccer field are necessary (Parsons and Jones 1998).

Training in preparation and competition are methods which are similar to each other because that's exactly where the sportsmen, the teams and some different training parameters for catching success among coaches are activated. Others include reaction and agility. As it is known, it reacts quickly to the football and reacts swiftly and with agile little touches you can change the result.

Reaction time goes along with a moderate arousal at the highest level and this is the most comfortable but it becomes very tense and worsens when it is in a relax environment (Robert 2013).

Success is achieved by first reaching a fast exit and then reaching the highest possible running speed, accelerating until it reaches the plateau at a speed of $40-60 \mathrm{~m}$ in a $100 \mathrm{~m}$ sprint run, muscle activation, which is higher in the accelerated state compared to the other phases during the stay, indicating that neural activity reaches maximum during acceleration and that neuromuscular ignition is important.

The type of reaction time experiment, the type of stimulus, and the stimulus density are the basic properties of any reaction time experiment, as well as many factors that affect the reaction time. One of the greatest factors influencing 
the duration of the reaction is 'stimuli' or it is striking, including muscle tension. Reaction time worsens when it is the most relaxed or very tense environment, with the moderate stimulus at the highest level (Robert 2013).

The reaction rate is defined as the time elapsed between the beginning of the stimulus and the beginning of the reaction. It is a component of speed and is an important influence on speed performance. Reaction speed is influenced by factors such as age, gender, nutrition, level of physical activity and fatigue. It is stated that the athletes in different branches are different and that athletes have better reaction speed than sedanters (Bavl1 2011).

According to Așc1 (2013), rapidity is seen as a part of agility when considering the necessity of accelerating the limbs in an explosive way in order to be able to change direction quickly and correctly (Karacabey 2013).

Agility is an important feature used in the vast majority of sports branches, but there are different definitions in the literature. It is defined as the ability to change the direction of the body or parts quickly and accurately (Urban et al.,1976).

According to Lemmink and his colleagues, agility is defined as the ability to change direction quickly, maintaining balance without loss of speed (Lemmink et al., 2004).

The Light Trainer system is a totally wireless reaction development and training system consisting of 8 laser sensors blue and green light transmitter and a central hand control unit. These 8 laser sensored LED lights are used to activate or deactivate users' movements. Various measurements relating to the users performance are made simultaneously.

The users can activate or deactivate the lights using any instrument (paddle, ball, bar, etc.) that holds their hands, feet, legs, heads or hands. The system is very easy to install and use. Exercise modes, difficulty and duration can be programmed. Laser sensor led lights can be mounted on wall, glass, mirror, floor or any device. This mobility feature allows a variety of exercises and training sessions while the user is on the train.

In addition, these laser sensored LED lights will simulate the real sports environment, such as tennis files, volleyball files, basketball files/potashes, soccer poles/filesine etc.which are mountable.

In general, the concepts of speed, agility and immediacy are discussed together in the literature received (SAQ). When we examined the agility feature, the most important of football performance was seen as one of the determinants. Adult and young with high agility profile players are more likely to perform better during high-speed repetitive actions and to make decisions quickly at crucial moments throughout the game. Agility model consists of two main components that change perceptual and decision making factors and the direction of speed

The aim of this study is to investigate the effect of light reaction exercises on agility-quickness and reaction time of u-20 football players.

\section{Method}

\section{Population-sampling}

The search group of this study is the U-20 footballers who play in Yeni Malatyaspor team. The study was conducted on a soccer team of 20 persons and two football players who were randomly divided into two groups of 10 persons. The mean age of the control group was $178.8 \pm 5.47 \mathrm{~cm}$, body weight average was $72.4 \pm 3.97 \mathrm{~kg}$, mean age was $18.6 \pm 0.51$ years and mean age of training was $9.1 \pm 0.73$ years. The mean age of the experimental group was $177.6 \pm 4.76 \mathrm{~cm}$, body weight was $71.9 \pm 3.75 \mathrm{~kg}$, mean age was $18.50 \pm 0.52$ years and mean age of training was $9 \pm 0.66$ years. The ethical approval of the research was taken by the Ethics Committee of the Non-Interventional Clinical Researches of Kocaeli University on projectnumber 2017/256 and decision no. 2017 / 13.6 on 04.10.2017.

\section{Data collection tools}

The data collection was done in Malatya, YeniMalatyaspor football stadium all participants were asked to refrain from alcohol, caffeine and ergogenic aids the day before the test.

According to the procedure, $20 \mathrm{~min}$. was given as warming time for the athletes. $5 \mathrm{~min}$. jogging and $10 \mathrm{~min}$. dynamic stretching with some different movements (upper, lower extremity and torso muscles) Dynamic exercises were applied.10-15rep. with 15sec resting time. After the warm up subjects were given the foot reaction test first and then the $\mathrm{t}$ test was performed.5 minutes between repetitions in each test, 10 minutes rest between tests. While the control group continued with the standard training, the exercise group performed the exercises with Light-Trainer for 8 weeks as well as standard training. At the end of the 8-weeks period, the same protocol was used for post-tests.

Light-Trainer (LTv2, Turkey) was used as a tool during reaction, agility, quickness exercises and also measurements.

The training was held during the competition season in the 2017/2018 football season. The training hours were 14:00 and three days a week for eight weeks. Agility-quickness and reaction exercises using light-trainer were applied for 20-25 minutes after the warm up, in the main phase of the training. The reaction exercises were done in 3 repetitions with 2 sets of $100 \%$ intensity. The quickness-agility exercises were done in 4 repetitions with 2 sets of $70-80 \%$ intensity. 
Tests

T Test

The subjects started at cone 1 . On the command of the timer, the subjects sprinted to cone 2 and touched the base of the cone with their right hands. They then turned left and shuffled sideways to cone 3 , and also touched its base, this time with their left hands. Then turned sideways to the right to cone 4 and touched the base with their right hands. They then turned back to cone 5 and touched it's base with their left hands, and ran backwards to cone 6 . The stopwatch was stopped as they passed cone 6 (https://www.topendsports.com/testing/tests/t-test.htm) (Figure 1).

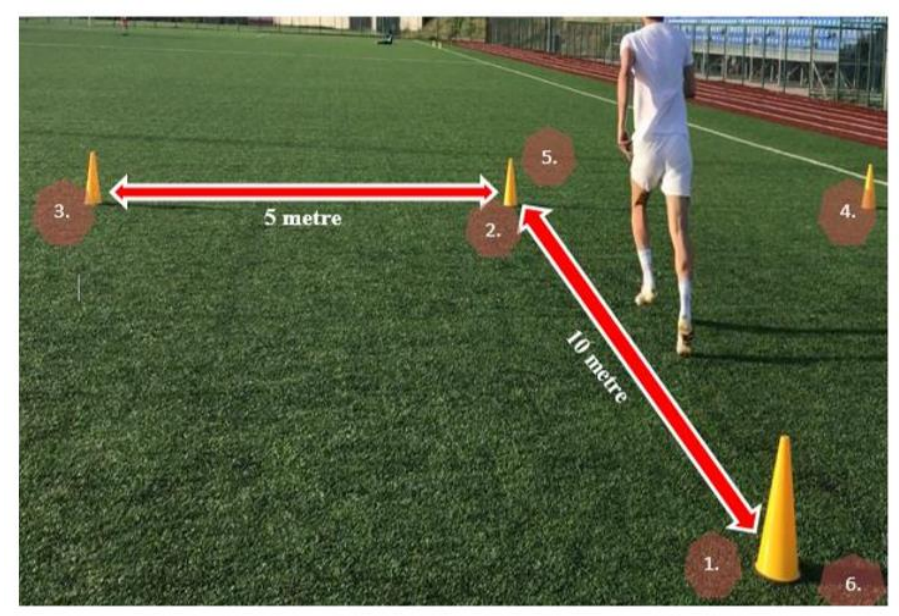

Figure 1. T Test

Foot Reaction Test

The subjects waited at the A point. They touched whichever module's light was on after the start command. Time was recorded (Figure 2).

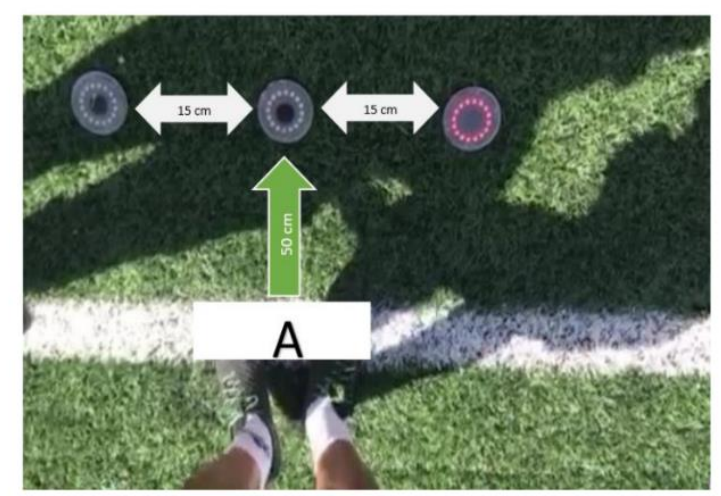

Figure 2. Foot Reaction Test

\section{Statistical analysis}

The statistical analysis of the obtained data in the SPSS 21.0 package program was made after the descriptive statistics and the percentage of development were calculated. The Wilcoxon test was used to compare pre-test and post-test data, and the mann-whitney $\mathrm{u}$ test was used to determine the differences between groups. Significance level was taken as $\mathrm{p}$ $<0.05$.

\section{Scientific Research Project Approval}

This study was supported by the 2017/108 BAP project number. 


\section{Findings}

Table 1. Mann-whitney test results of pre-test values of research groups

\begin{tabular}{|c|c|c|c|c|c|c|}
\hline & & & $\mathbf{N}$ & $($ Mean \pm SD $)$ & $\mathbf{z}$ & $\mathbf{P}$ \\
\hline \multirow{5}{*}{$\begin{array}{l}\text { PRE } \\
\text { TEST }\end{array}$} & \multirow{3}{*}{ T TEST } & Experimental & 10 & $10.16 \pm 0.49$ & \multirow{3}{*}{-1.173} & \multirow{3}{*}{0.241} \\
\hline & & & & & & \\
\hline & & Control & 10 & $9.84 \pm 0.36$ & & \\
\hline & \multirow{2}{*}{$\begin{array}{l}\text { FOOT } \\
\text { REACTION }\end{array}$} & Experimental & 10 & $0.43 \pm 0.06$ & \multirow{2}{*}{-0.304} & \multirow{2}{*}{0.791} \\
\hline & & Control & 10 & $0.42 \pm 0.29$ & & \\
\hline
\end{tabular}

As seen in Table 1, there was no statistically significant difference in the parameters of T-Agility test and foot reactions when the pre-test values of the research groups were compared $(p>0.05)$.

Table 2. Mann-whitney test results of the final test values of the research groups

\begin{tabular}{cllllll}
\hline & & & N & (Mean \pm SD) & Z & P \\
\hline \multirow{2}{*}{ POST } & T TEST & Experimental & 10 & $9.49 \pm 0.55$ & -2.117 & $\mathbf{0 . 0 3 4 *}$ \\
TEST & & Control & 10 & $9.85 \pm 0.35$ & & \\
& FOOT & Experimental & 10 & $0.37 \pm 0.06$ & & -2.046 \\
& REACTION & Control & 10 & $0.42 \pm 0.29$ & & $\mathbf{0 . 0 4 1 *}$
\end{tabular}

As seen in Table 2, statistically significant differences were found in the parameters of T-Agility test and foot reactions of research groups ( $<0.05)$. This difference appears to be in favour of the experimental group.

Table 3. Wilcoxon test results of pre-test and post-test values of control group

\begin{tabular}{|c|c|c|c|c|c|c|}
\hline & & & $\mathbf{N}$ & $($ Mean \pm SD $)$ & $\mathbf{z}$ & $\mathbf{p}$ \\
\hline \multirow{4}{*}{$\begin{array}{l}\text { CONTROL } \\
\text { GROUP }\end{array}$} & \multirow{2}{*}{ T TEST } & Pre Test & 10 & $9.84 \pm 0.36$ & \multirow{2}{*}{-0.971} & \multirow{2}{*}{0.331} \\
\hline & & Post Test & 10 & $9.85 \pm 0.35$ & & \\
\hline & FOOT & Pre Test & 10 & $0.42 \pm 0.29$ & \multirow{2}{*}{-0.900} & \multirow{2}{*}{0.368} \\
\hline & REACTION & Pos Test & 10 & $0.42 \pm 0.29$ & & \\
\hline
\end{tabular}

As seen in Table 3, there was no statistically significant difference between the pretest-posttest values of the control group and t-agile and foot reactions parameters $(\mathrm{p}>0.05)$.

Table 4.Wilcoxon test results of the pre-test and post-test values of the 5th experiment group

\begin{tabular}{lllllll}
\hline & & N & (Mean \pm SD) & z & p \\
\hline EXPERİ & T TEST & Pre Test & 10 & $10.16 \pm 0.49$ & -2.803 & $\mathbf{0 . 0 0 5}^{*}$ \\
MENTAL & & Post Test & 10 & $9.49 \pm 0.55$ & & \\
GROUP & FOOT & Son Test & 10 & $14.01 \pm 0.51$ & & -2.842 \\
& REACTION & Pre Test & 10 & $0.43 \pm 0.06$ & $\mathbf{0 . 0 0 4 *}$
\end{tabular}

As seen in Table 4, when the pretest-posttest values of the experimental group were compared statistically, significant differences were found in the parameters of $\mathrm{T}$ - agility and foot reactions test $(\mathrm{p}<0.05)$. This difference indicates that the mean values of all parameters are decreasing and this shows that our study is effective.

When the tables were examined in general, it was observed that the agility-quickness and foot reaction values before Light-Trainer exercises were significantly higher after Light-Trainer exercises. .

\section{Results, Conclusions and Recommendations}

The present study aims at determining the effect of the light trainer device on the reaction and agility different hook punch techniques in boxing. Although the literature does not directly focus on the Light-Trainer device, many studies 
show that rapidity-agility and reaction duration can be improved with different training. According to Milanovic (2013), SAQ (Speed, Agility, Quickness) program should be a part of routine football training after the findings of researches on the effect of SAQ (Agility, Agility, Quickness). Jovanovic (2011) noted that SAQ (training, agility, and agility) training members provide faster sporting performance improvements over random conditions when programmed with gradual advancement of exercise and equipment made of neural stimuli. Sporis et al. (2011) showed that the agility movements made with the ball were more complicated when compared to those without the ball and showed that basic skills without ball had a stronger link between speed, quickness- and agility. İt was mentioned as an essential feature that is essential for agility and in the majority of sports branches.

As a result of the reaction and correct decision-making exercises on young footballers, there has been a positive increase in the speed of the players to make correct decisions and reactions (Vaeyens et al., 2007).

When we compare the $t$ agility test results generally constructed under the age of 20 , with the averages of the $t$ agility test results of our own study, they are close to the test results of our own group.

Our study showed that though both groups were developed, there is a statistically significant improvement in agility and reaction parameters in the exercise group $(\mathrm{p}<0.05)$. Development level was different. The $\mathrm{T}$ agility test of the exercise group was $6 \%$ (pretest: 10.16 , posttest: 9.49 ) and the reaction rate was $3 \%$ test: 0.43 , final test: 0.37 ). For the control group, the $\mathrm{T}$ agility test showed $2 \%$ (pretest: 9.84 , final test: 9.85 ) and $1 \%$ (pretest: 0.42 , posttest: 0.42 ) in the reaction speed test but $1 \%: 14.38$, post test: 14.56$)$.

In Milanovic's (2013) study, SAQ (speed, agility, and quickness) training in bulk and without ball is an effective way of improving agility for young footballers and may be included in physical fitness programs. In another study which showed similarity with our own studies, it was seen that the reaction studies made with different exercise methods have a positive effect on the reaction duration. Sever and Arslanoglu (2016) was found to be 10.31 for male soccer players under age 18 and $\mathrm{A} 2$ teams in a study that was close to their own unemployment age group. This result is in line with the test average of our own study in terms of both the age group and the t-test result average. In addition, a remarkable approach has shown that such different types of exercise methods have contributed significantly to the focus (Pesce et al., 2007). Reaction capability is an essential feature for performance athletes to take action and use their existing skills. In an effort to do so, soccer players, moving balls and other players must be seen at visual distances and at different distances, indicating that football is important in terms of reacting and responding to objects of different sizes and shapes (Ando et al., 2001).The reaction times of high performance sprinter are shorter than those of low performance sprinter. The warm-up period can be improved by a certain degree with warming and exercise. Exercise creates a stimulus to highly educated athletes that promotes alertness to external environmental influences. Although the exercises on the reaction have a certain effect after a certain period of time, doing these exercises at intervals does not affect the reaction development. The decrease in reaction time and the increase in the number of correct reactions in the exercise control groups are probably due to learning processes and due to the continuous reaction exercises in the correct reaction (Lemmink and Visscher 2005).

As a result, it was decided that the exercises made with the light reaction device have both positive effects on the speed of the reaction and improvement of the characteristics on the U-20 footballers in improving agility-quickness properties. Percentage of development was also higher than that of normal routine exercises.

\section{Recommendations}

The light reaction can be used effectively in the field of spore performance to improve agility-quickness and reaction speed of your exercises. With this type of training device, classical training can be removed from one level and learning accelerated with innovative exercise models. Such exercise devices may allow athletes to concentrate more on training and to have a more enjoyable training process with different modes of the device because of the difference. It can also be used in the form of functional training techniques during rehabilitation periods for athletes.

\section{References}

Ando, S., Kida, N., \& Oda, S. (2000). Central and peripheral visual reaction time of soccer players and nonathletes. Perceptual and Motor Skills. 92(3), 786-794. https://doi.org/10.2466/pms.2001.92.3.786

Aydos, L., Taş, M., \& Akyüz, M. (2009). Genç Elit Güreşçilerde Kuvvetle Bazı Antropometrik Paremetrelerin İlişkisinin İncelenmesi. Journal of Physical Education and Sport Sciences. 11(4), 1-10.

Bavlı, Ö. (2011). Farklı Zeminlerde Uygulanan Sürat Çalışmalarının Sürat ve Reaksiyon Sürati Performansı Üzerine Etkisinin İncelenmesi, Selçuk Üniversitesi Beden Eğitimi Ve Spor Bilim Dergisi, 13(1), 100-102

Jovanovic, M., Sporis, G., \& Omrcen, D. (2011). Effects of speed, agility, quickness training method on power performance in elite soccer players. The Journal of Strength \& Conditioning Research, 25(5), 1285-1292. 
https://doi.org/10.1519/JSC.0b013e3181d67c65

Koç, H., \& Aslan, C. S. (2010). Erkek hentbol ve voleybol sporcularının seçilmiş fiziksel ve motorik özelliklerinin karşılaştırılması. Selçuk Üniversitesi Beden Eğitimi ve Spor Bilim Dergisi, 12(3), 227-231.

Lemmink, K. A., \& Visscher, C. (2005). Effect of intermittent exercise on multiple-choice reaction times of soccer players. Perceptual and Motor Skills, 85-95. https://doi.org/10.2466/pms.100.1.85-95

Milanović, Z., Sporiš, G., \& Trajković ve diğ. (2013). Effects of a 12 week saq training programme on agility with and without the ball among young soccer players. Journal of Sports Science \& Medicine, 12(1), 97.

Parsons, L. S., \& Jones, M. T. (1998). Development of Speed, Agility, and Quickness for Tennis Athletes. Strength \& Conditioning Journal, 20(3), 14-19. https://doi.org/10.1519/1073-6840(1998)020<0014:DOSAAQ>2.3.CO;2

Pesce, C., Tessitore, A., \& Casella, R. (2007). Focusing of visual attention at rest and during physical exercise in soccer players. Journal of sports sciences, (11), 1259-70. https://doi.org/10.1080/02640410601040085

Schank, R. C., \& Abelson, R. P. (2013). Scripts, plans, goals, and understanding: An inquiry into human knowledge structures. Psychology Press. https://doi.org/10.4324/9780203781036

Sever, O., \& Arslanoğlu, E. (2016). Futbolcularda yaşa bağlı çeviklik, ivmelenme, sürat ve maksimum sürat ilişkisi. Journal of Human Sciences, 13(3), 5660-5667.

Sporis, G., Milanovic, Z., \& Trajkovic, N. (2011) Correlation between speed, agility and quickness (SAQ) in elite young soccer players. Acta kinesiologica, 5(2), 36-41.

Urban, J., Chelladurai, M., Millership, A., \& Schreiber, G. (1976). The Kinetics in vivo of the Synthesis of AlbuminLike Protein and Albumin in Rats. European journal of biochemistry, 67(2), 477-485. https://doi.org/10.1111/j.1432-1033.1976.tb10713.x

Vaeyens, R., Lenoir, M., \& Williams, A. M. (2007). The effects of task constraints on visual search behavior and decision-making skill in youth soccer players. Journal of Sport and Exercise Psychology, (2), 147-169. https://doi.org/10.1123/jsep.29.2.147

\section{Copyrights}

Copyright for this article is retained by the author(s), with first publication rights granted to the journal.

This is an open-access article distributed under the terms and conditions of the Creative Commons Attribution license which permits unrestricted use, distribution, and reproduction in any medium, provided the original work is properly cited. 